Missio Ecclesiae, 5(2), Oktober 2016, 102-133

\title{
RELEVANSI LUKAS 10:1-12 BAGI HAMBA TUHAN SEBAGAI PELAKSANA MISI ALLAH
}

\section{Olivia Masihoru}

\section{PENDAHULUAN}

Kabar Baik bisa didengar oleh banyak orang jika ada yang memberitakannya. Pemberitaan Kabar Baik merupakan tugas gereja dan orang percaya untuk melaksanakan misi Allah di dunia. Namun Tuhan juga menetapkan orang-orang tertentu yang diberi tugas khusus untuk pergi menyampaikan Kabar Baik itu. Orang yang dipanggil dan dikhususkan untuk melakukan pekerjaan menyampaikan Kabar Baik adalah orang yang mempunyai tujuan untuk mengabdikan waktu dan tenaganya bagi pelayanan khusus itu, yang diberikan Allah kepadanya. ${ }^{1}$

Penginjilan adalah membagi atau memberitakan Kabar Baik kepada orang lain. Kabar baik tersebut ialah Yesus Kristus sendiri yang diberitakan oleh Gereja bahwa Ia telah mati bagi penebusan manusia berdosa". ${ }^{2}$ Tugas penginjilan merupakan perintah Tuhan kepada semua orang percaya yang harus dilaksanakan, khususnya kepada orang-orang yang dipanggil dan diberi tugas khusus untuk menyampaikan Kabar Baik. Tugas ini harus dilaksanakan, seperti yang diungkapkan oleh Keith Brown bahwa: "Perintah dalam Alkitab maksudnya ialah untuk ditaati oleh siapa saja atau semua orang yang mengaku setia mengikut Yesus Kristus sebagai Juruselamat dan Tuhannya.”

Dunia merupakan ladang misi yang sangat luas, dengan demikian membutuhkan pekerja-pekerja untuk pekerjaan menuai jiwa-jiwa. ${ }^{4}$ Ladang misi membutuhkan orang-orang atau hamba Tuhan yang punya hati misi. Leroy

\footnotetext{
${ }^{1}$ Billy Graham, Beritakan Injil, (Yogyakarta: Yayasan ANDI, 1992), 48

${ }^{2}$ Stevri Lumintang, Teologi Abu-Abu, (Batu-Malang: Departemen Literatur YPPII, 2002), 401

${ }^{3}$ Keith Brown, Pelayanan Misi dalam Gereja-Gereja Lokal di Asia, (Batu-Malang: Departemen Misi YPPII), 1

${ }^{4}$ Trougott Boeker, Misi: Kasih Yang Mencari, (Batu-Malang: Departemen Literatur YPPII, 1985), 47
} 
Eims mengemukakan bahwa: "Berjuta-juta orang yang lemah, susah, tidak berdaya, memerlukan sentuhan Allah yang segar dan memberikan semangat dalam hidup mereka melalui orang-orang yang kita doakan menurut perintah Allah: yaitu para pekerja". ${ }^{5}$ Allah membutuhkan pekerja yang banyak untuk mengerjakan misi-Nya yang besar di dalam dunia ini, karena jiwa-jiwa atau tuaian sangat banyak dan tidak sebanding dengan jumlah yang melayani. ${ }^{6}$

Alkitab merupakan buku misi, di mana Kristus adalah pusat dari seluruh Alkitab, dengan demikian Kristus menjadi pusat misi Allah dalam Alkitab. ${ }^{7}$ Injil Lukas merupakan salah satu kitab dalam Alkitab, dengan demikian Lukas adalah buku misi. Yesus Kristus adalah Juruselamat dunia merupakan ciri khas bagi Injil Lukas. ${ }^{8}$ Injil Lukas bukan hanya untuk memahami misi Kristus melainkan juga misi Gereja di tengah-tengah dunia ini. ${ }^{9}$

Dari beberapa kitab Injil lainnya hanya Lukas yang mencatat tentang penugasan tujuh puluh murid untuk memberitakan Injil (Luk 10:1-24). ${ }^{10}$ Dari teks ini khususnya pada ayat 2, Yesus memberikan gambaran bagi muridmurid-Nya bahwa "Tuaian memang banyak, tetapi pekerja sedikit (2a). Hal ini memberikan gambaran bahwa tuaian atau jiwa-jiwa yang perlu diselamatkan begitu banyak, sudah menguning dan siap untuk dituai. Namun yang menjadi kendala, para pekerja yang akan menuai tuaian tersebut sangat sedikit. Para murid diutus oleh Tuhan Yesus untuk pergi ke ladang-Nya yang sudah menguning. Namun menurut Tuhan Yesus jumlah penuai sedikit, sedangkan ladang luas. Karena itu selain mereka diutus, mereka juga harus meminta supaya dikirim para pekerja untuk tuaian tersebut. Para hamba Tuhan harus lebih lagi memahami tentang pelayanan misi sebagaimana dinyatakan dalam Injil Lukas 10:1-12, karena para hamba Tuhan adalah pelaksana misi Allah.

${ }^{5}$ Leroy Eims, Penuai yang di Perlengkapi, (Malang: Gandum Mas, 1988), 18

${ }^{6}$ Makmur Halim, Misi Diskusi dan Doa, (Malang: Gandum Mas, 1988), 40

${ }^{7}$ Ibid., 404

${ }^{8}$ Ola Tulluan, Introduksi Perjanjian Baru, (Batu: Departemen Literatur YPPII, 1999),

${ }^{9}$ David J. Bosch, Transformasi Misi Kristen, (Jakarta: BPK Gunung Mulia, 2005), 130131

10 __ The Wycliffe Bible Commentary, (Malang: Gandum Mas, 2001), 248 
Missio Ecclesiae, 5(2), Oktober 2016, 102-133

\section{ANALISA EKSEGETIS LUKAS 10:1-12}

Pada bagian ini penulis akan menguraikan mengenai analisa eksegetis Lukas 10:1-12, di mana didalamnya penulis akan menganalisa latar belakang dari Injil Lukas, menganalisa konteks Lukas 10:1-12 baik konteks dekat maupun jauh, dan mengeksegese bagian teks Lukas 10:1-12.

\section{$\underline{\text { Analisa Latar Belakang Injil Lukas }}$}

Injil Lukas seperti Injil-injil yang lain juga, ditulis oleh orang tertentu dalam lingkungan jemaat dan pada zaman tertentu serta dengan maksud tertentu. Untuk mengerti atau memahami isi dari Injil Lukas, maka harus dipahami terlebih dahulu latar belakang penulisannya.

\section{Penulis}

Menurut tradisi gerejawi mula-mula, penulis Injil Lukas adalah Lukas sendiri. ${ }^{11}$ Pengakuan ini sudah sejak pertengahan abad kedua. ${ }^{12}$ Hampir semua ahli theologia juga sependapat bahwa Injil Lukas dan Kisah para Rasul ditulis oleh orang yang sama karena kedua kitab ini dialamatkan kepada orang yang sama. ${ }^{13}$

Lukas adalah seorang Yunani dan satu-satunya penulis Perjanjian Baru yang bukan Yahudi. Diperkirakan Ia dilahirkan di Antiokhia di Pisidia dan Filipi di Makedonia. Dia dinamakan Lukas oleh orang tuanya berdasarkan singkatan dari suatu nama Romawi Lucanos. Lukas bukanlah salah seorang murid Tuhan Yesus. Kemungkinan Lukas bertobat karena dilayani Paulus ketika Paulus tinggal di Antiokhia, sebagaimana yang disebut dalam Kisah Para Rasul 11:25-26. Lukas memiliki banyak bakat dan panggilan yaitu sebagai dokter, sebagaimana diungkapkan Paulus "Tabib Lukas yang kekasih" (Kol. 4:14). Lukas juga merupakan ahli sejarah, dapat dilihat melalui perhatiannya terhadap sejarah, di mana Injilnya banyak mengutip data-data sejarah (misalnya 1:5,25,56 2:1,2,21-22,36-37,42;3:1-2. Lukas juga memiliki bakat sebagai seorang penulis di mana bagi banyak orang, Injilnya merupakan suatu karya sastra yang hebat, dan juga ia sebagai seorang Penginjl dan Pendeta yang

\footnotetext{
${ }^{11}$ J.L Ch. Abineno, Yesus Juruselamat Dunia, (Jakarta: BPK Gunung Mulia), 6

${ }^{12}$ Marulak Pasaribu, Eksposisi Injil Sinoptik, (Malang: Gandum Mas, 2005), 169

${ }^{13}$ Ola Tuluan, Introduksi ..., 50
} 
merupakan teman sekerja Rasul Paulus dalam perjalanan mengabarkan Injil dan selalu bersama Paulus hingga saat Paulus meninggal (Kol.1:14, Flm24, 2Tim4:11). ${ }^{14}$ Tenney dalam bukunya menyatakan bahwa:

Lukas bukanlah seorang penonton biasa, ia melihat kebenaran kekristenan dari luar kalangannya, tetapi ia sendiri ialah seorang pengkhotbah dan penginjil yang aktif. Ia adalah penulis sejarah gereja dan seorang sastrawan pendukung agama Kristen yang pertama. Karena ia adalah rekan Paulus dapatlah dimengerti bila karyanya mencerminkan pengetahuan Kristiani yang biasa digunakan untuk mengajar umat yang bukan Yahudi. ${ }^{15}$

Lukas bukanlah saksi mata yang menyaksikan secara langsung kehidupan dan pelayanan Tuhan Yesus. Namun demikian, semua peristiwa yang dilaporkan dalam tulisannya berdasarkan hasil penelitian yang didapatnya dari para saksi mata (Luk1:1-4). Ada tradisi yang mengatakan bahwa Lukas dalam hidupnya tidak menikah, dan meninggal pada umur delapan puluh empat tahun. ${ }^{16}$

\section{Waktu dan Tempat Penulisan}

Injil Lukas ditulis sebelum Kisah Para Rasul, hal ini dapat dilihat pada kalimat "Buku yang pertama" (Kis 1:1), dan penulisan Kisah Para Rasul waktu Paulus dipenjarakan di Roma pertama kali (Bnd. Kis28). Injil ini ditulis sekitar tahun enam puluh. ${ }^{17}$ Tenney dalam bukunya menyatakan bahwa:

Mungkin tahun enampuluh dapat dijadikan sebagai patokan, karena pada saat itu Lukas menjadi orang Kristen selama sekurangkurangnya sepuluh tahun atau lebih dan sudah menjelajahi Palestina, dimana ia pasti sudah bertemu dengan mereka yang pernah menyaksikan Yesus dengan mata kepala sendiri. Mungkin ia mengisi waktu ketika Paulus berada di penjara dengan menyelidiki latar

\footnotetext{
${ }^{14}$ Irving L Janson, Lukas - Buku Penuntun Belajar, (Bandung: Kalam Hidup), 10-11

${ }^{15}$ Merrill C. Tenney, Survei Perjanjian Baru (Malang: Gandum Mas, 1992), 220

${ }^{16}$ Marulak Pasaribu, Eksposisi...170

${ }^{17}$ Ola Tuluan, Introduksi...53
} 
Missio Ecclesiae, 5(2), Oktober 2016, 102-133

belakang kehidupan Yesus, tentang siapa ia sudah mendengar begitu banyak dan untuk siapa ia menjadi seorang utusan Injil. ${ }^{18}$

Dalam Injil Lukas tidak ada petunjuk yang jelas mengenai tempat penulisannya. Kemungkinan Injil ini ditulis di luar Palestina, di Kaisarea atau di Roma. Tidak ada tradisi yang pasti mengenai tempat Injil ini ditulis. Yang jelas, ia pasti ditulis di suatu tempat di wilayah Helenis oleh seseorang yang bekerja di antara umat asing bukan Yahudi. ${ }^{19}$

\section{Alamat Penulisan}

Injil Lukas dialamatkan kepada Theofilus (Luk. 1:3). Theofilus adalah seorang Yunani yang berasal dari keturunan bangsawan dan kemungkinan besar telah menjadi pengikut Yesus. ${ }^{20}$ Theofilus adalah seorang yang berkedudukan tinggi dalam masyarakat, ini dapat dilihat dari sebutan Lukas "Theofilus yang mulia". Untuk menulis surat kepada orang yang berkedudukan tinggi sudah menjadi kebiasaan pada waktu itu, supaya melalui mereka dapat diteruskan kepada orang-orang lain. Theofilus berlatarbelakang agama kafir, ini menunjukkan bahwa dia bukan orang Yahudi. Hal ini dapat dilihat dari dua sebab yaitu: Pertama, Lukas menjelaskan tentang geografi Palestina, hal itu tidak perlu untuk orang Yahudi (band.Luk. 1:26; 2:4; 4:31 dst). Kedua, ketika Lukas membuat catatan peristiwa-peristiwa penting, dia menghubungkan dengan sejarah umum dan tidak dengan sejarah Yahudi secara khusus (Luk. 1:5, 2:1-2, 3:1). ${ }^{21}$ Pasaribu menulis dalam bukunya bahwa: "Jika Injil Lukas pertama-tama ditujukan kepada Theofilus, itu tidak berarti bahwa Injil Lukas hanya terbatas atau berlaku untuk seorang saja, melainkan juga untuk para pembaca yang berlatarbelakang Yunani, Romawi, Yahudi bahkan untuk semua". 22 Dengan demikian Injil ini ditujukan pertama-tama kepada Theofilus yang berkedudukan tinggi dengan maksud supaya tulisan ini diteruskan kepada orang-orang lain atau kalangan yang lebih luas. Seperti juga diungkapkan Drewes demikian:

\footnotetext{
${ }^{18}$ Merril Tenney, Survei...220-221

${ }^{19}$ Merril Tenney, Survei..., 221

${ }^{20}$ Marulak Pasaribu,Eksposisi... 172

${ }^{21}$ Ola Tuluan, Introduksi...52-53

${ }^{22}$ Marulak Pasaribu, Eksposisi... 172
} 
Perlu diketahui bahwa pada zaman Lukas, penyerahan suatu buku kepada seseorang dilakukan umpamanya dengan harapan bahwa beliau yang diserahi itu akan memperbanyak karangan yang bersangkutan, sebab usaha ini membutuhkan modal untuk membiayai bahan dan tenaga. Jadi, jangan kita menganggap Injil Lukas sebagai semacam surat pribadi saja. $^{23}$

\section{Tujuan Penulisan}

Tujuan Lukas menulis Injil ini seperti yang dinyatakan dalam pasal 1:1-4 yaitu untuk membukukan dengan teratur kebenaran mengenai pekerjaan Tuhan Yesus. ${ }^{24}$ Ada beberapa pokok mendasar yang ingin disampaikan oleh Lukas dalam menuliskan Injilnya yaitu: (1) Lukas mau menjelaskan bagaimana hubungan keselamatan yang Yesus kerjakan tersedia bukan hanya untuk orang Yahudi saja melainkan juga untuk bangsa-bangsa lain di luar Yahudi. (2) Lukas ingin menjelaskan mengenai pribadi dan pengajaran Yesus dalam hubungannya dengan rencana keselamatan Allah bagi seluruh dunia yang berlaku sepanjang masa. (3) Lukas hendak mendefenisikan tentang misi Yesus datang ke dunia, dan misi pengutusan para murid bagi keselamatan umat bukan hanya khusus orang Israel tetapi seluruh bangsa. (4) Lukas hendak mencatat sebuah laporan tentang perjalanan kehidupan Yesus dengan meneliti secara seksama berdasarkan bukti-bukkti nyata yang didapatnya dari para saksi mata. (5) Lukas ingin memperkenalkan Yesus yang adalah Mesias, Anak Allah (Luk. 3:22,38, dll). (6) Lukas ingin mencatat asal mula dan perkembangan kekristenan mulai dari Galilea sampai ke Roma. Ia ingin membuktikan bahwa ternyata perkembangan kekristenan adalah fakta sejarah di mana Allah bekerja melalui Yesus Kristus. (7) Lukas ingin melaporkan kepada Theofilus bahwa kekristenan bukanlah ancaman bagi penguasa Romawi sebab kekristenan adalah iman kepada Yesus yang menyelamatkan manusia dari dosa. Lukas mau menjelaskan bahwa Yesus datang bukan hanya untuk orang Yahudi tetapi untuk semua orang, dan Yesus adalah Juruselamat mereka yang tertindas, hina, manusia berdosa dan sebagainya. ${ }^{25}$ Jadi maksud Lukas menulis Injil ini supaya orang yang bukan Yahudi tahu bahwa Yesus adalah Juruselamat umat manusia, dan

\footnotetext{
${ }^{23}$ B.F Drewes, Satu Injil Tiga Pekabar, (Jakarta: BPK Gunung Mulia, 2001), 254

${ }^{24}$ Irving Jansen, Lukas... 12

${ }^{25}$ Marulak Pasaribu, Eksposisi...170-171
} 
bahwa Injil ini berlaku untuk semua golongan, baik mereka yang tertindas, miskin, maupun para bangsawan untuk semua suku dan bangsa.

\section{$\underline{\text { Analisa Konteks }}$}

Kata konteks adalah kata yang dipakai untuk menunjukkan hubungan yang menyatukan bagian Alkitab yang hendak ditafsir dengan sebagian atau seluruh Alkitab. Analisa konteks dibagi dalam pengertian konteks dekat dan konteks jauh. ${ }^{26}$ Di bawah ini penulis akan menguraikan mengenai konteks dari Lukas 10:1-12 baik konteks dekat maupun jauh.

\section{Konteks Jauh}

Konteks jauh adalah konteks yang menunjuk pada konteks yang lebih jauh atau luas. Fungsinya mungkin tidak begitu jelas dalam penentuan batas suatu kalimat atau penentuan arti kata, tetapi konteks ini sangat bermanfaat untuk menyelidiki jalan pemikiran atau maksud dari bagian yang ingin ditafsir bahkan dari seluruh kitab. $^{27}$

Hanya Injil Lukas yang mencatat mengenai pengutusan ketujuh puluh murid. Ayat-ayat dalam Lukas 10:1-12 ini parallel dengan ayat-ayat yang ada dalam Matius 9:37-38, 10:7-16 ; Markus 6:8-11 ; Lukas 9:3-5. Teks ini dikisahkan Lukas dalam perjalanan Yesus menuju Yerusalem, yang dapat dilihat dalam ayat sebelumnya (9:52). Dalam Injil Matius, pengutusan kedua belas murid menunjuk pada pengutusan kepada orang Israel (Mat 10:5-15).

Lukas dalam Injilnya mau menekankan bahwa pengutusan tujuh puluh murid menunjukkan pada pengutusan kepada segala bangsa. ${ }^{28}$ Tugas para murid adalah memberitakan tentang kerajaan Allah di mana berita ini harus disampaikan kepada semua orang.

\section{Konteks Dekat}

${ }^{26}$ Hasan Sutanto, Hermeneutik: Prinsip dan Metode Penafsiran Alkitab, (Malang: Seminari Alkitab Asia Tenggara, 1986), 205

${ }^{27}$ Ibid., 207-208

${ }^{28}$ B.F Drews, Satu Injil ..., 324 
Konteks dekat adalah konteks yang menunjuk ayat-ayat yang berkisar sebelum dan sesudah ayat-ayat yang hendak ditafsir, untuk melihat apakah ayat-ayat yang ingin ditafsir adalah suatu kesatuan yang utuh. ${ }^{29}$ Teks Lukas 10:1-12 ini berkaitan dengan teks-teks sebelumnya pada pasal 9 mengenai pengutusan kedua belas murid. Pengutusan ketujuh puluh murid berkaitan dengan pengutusan dua belas murid karena dalam pengutusan tersebut mengandung instruksi-instruksi yang sama atau tugas yang diberikan bagi mereka sama, untuk dilaksanakan dalam memberitakan tentang kerajaan Allah. Teks Lukas 10:1-12 ini juga berkaitan dengan pasal sebelumnya pada ayat 52, di mana Yesus memberikan suatu tugas dan ini merupakan kewajiban para murid untuk mendahului-Nya mempersiapkan tempat yang akan dikunjungi oleh Yesus. Teks ini juga berkaitan dengan teks sesudahnya, di mana setelah itu Lukas menulis mengenai keberhasilan ketujuh puluh murid yang diutus dalam melaksanakan tugas (10:17-20) dan teks selanjutnya ucapan syukur Yesus atas pelayanan murid-murid-Nya (10:21-24).

\section{Eksegese Lukas 10:1-12}

Pada bagian ini, penulis akan membuat uraian eksegetis secara mendalam terhadap beberapa kata dalam Lukas 10:1-12, sehingga dapat diketahui makna dan arti yang sebenarnya dari teks tersebut.

\section{Penunjukan dan Pengutusan Tujuh Puluh Murid (ay. 1)}

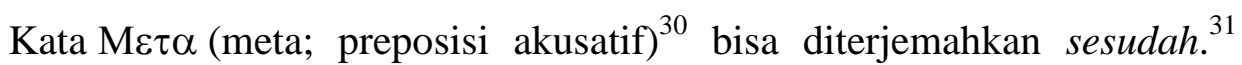
Dalam NIV, KJV dan NASB menterjemahkan after. Hal ini menunjuk kepada peristiwa atau hal-hal yang terjadi sebelum pengutusan tujuh puluh murid. Kata berikutnya $\alpha v \varepsilon \delta \varepsilon \imath \chi \varepsilon v$ (anedeizen; aorist, indikatif, aktif, orang ke 3 tunggal), ${ }^{32}$

${ }^{29}$ Ibid., 206

${ }^{30}$ Barbara dan Timothy Friberg, Analytical Greek New Testament, (Grand Rapids, Michigan: Baker Book House, 1975), 216

${ }^{31}$ Barclay M. Newman, Kamus Yunani Indonesia, (Jakarta: BPK Gunung Mulia, 2002), 106

${ }^{32}$ Barbara dan Timothy, Analytical Greek..., 216 


\section{Missio Ecclesiae, 5(2), Oktober 2016, 102-133}

dari kata $\alpha \nu \alpha \delta \varepsilon \imath \kappa v \cup \mu \imath$ (anadeiknumi) yang memiliki arti telah menunjuk. ${ }^{33}$ Terjemahan yang sama juga diikuti oleh LAI, sedangkan NIV, NASB dan KJV menterjemahkan appointed (telah menetapkan). Kata ini ditulis dalam bentuk aorist indikatif aktif yang menunjuk kepada suatu tindakan yang dulu telah dilakukan dan dampak dari tindakan itu terus-menerus dialami. Kata appointed yang ditulis dalam KJV, nampaknya lebih tepat, di mana Tuhan Yesus menetapkan tujuh puluh murid-Nya untuk mengerjakan suatu tugas. Dalam The Expositor's Bible Commentary ditulis bahwa: ... they come from the Lord Jesus himself, ${ }^{34}$ maksudnya adalah bahwa para murid itu benar-benar datang atau berasal dari Yesus sendiri, karena Dia yang telah menunjuk atau menetapkan mereka.

Kata berikutnya adalah $\alpha \pi \varepsilon \sigma \tau \varepsilon \imath \lambda \varepsilon v$ (apesteilen; aorist, indikatif, aktif, orang ke-3 tunggal), ${ }^{35}$ berasal dari kata $\alpha \pi \sigma \sigma \tau \varepsilon \lambda \lambda \mathrm{o}$ (apostello) diterjemahkan to send out, ${ }^{36}$ artinya mengutus, menyuruh, mengirim. ${ }^{37}$ Kata ini dipakai 132 kali dalam Perjanjian Baru. ${ }^{38}$ Maka kata $\alpha \pi \varepsilon \sigma \tau \varepsilon \imath \lambda \varepsilon v$ dapat diterjemahkan: telah mengutus/menyuruh/mengirim. Terjemahan yang sama dari kata ini juga diikuti oleh NIV, KJV, NASB dan LAI. Kata tersebut diawali dengan kata

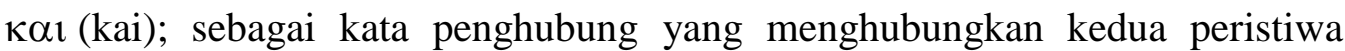
yang telah dilakukan oleh Tuhan Yesus, yaitu setelah Dia menunjuk para murid, kemudian Dia mengutus mereka.

Kata $\alpha v \alpha \delta$ o (ana duo), ${ }^{39}$ terdiri dari kata $\alpha v \alpha$ yang bisa diterjemahkan di antara, menurut giliran, masing-masing. ${ }^{40}$ Kata $\delta$ o (duo) artinya dua. ${ }^{41} \mathrm{Jadi}$ kata ana duo memiliki pengertian berdua-dua. Para murid diutus berdua-dua sesuai dengan aturan bahwa kesaksian dua orang berlaku dan dapat dipercaya

${ }^{33}$ Barclay, Kamus Yunani..., 9

${ }^{34}$ Frank E. Gaebelein, The Expositor's Bible Commentary, (Grand Rapids, Michigan: Regency Reference Library, 1984), 937

${ }^{35}$ Barbara dan Timothy, Analytical Greek..., 216

${ }^{36}$ Fritz Rienecker, A Linguistik Key To The Greek New Testament, (Grand Rapids, Michigan: Reference Library, Regency, 1976), 169

${ }^{37}$ Barclay, Kamus Yunani..., 20

${ }^{38}$ Hasan Sutanto, Perjanjian Baru Interlinear Konkordansi Jilid II, (Jakarta: Lembaga Alkitab Indonesia, 2004), 105

${ }^{39}$ Barbara dan Timothy, Analytical Greek..., 216

${ }^{40}$ Hasan Sutanto, Perjanjian Baru..., 60

${ }^{41}$ Horst Balz dan Gerhard Schneider, Exegetical Dictionary of The New Testament. Grand Rapids, Michigan: William B. Erdmans Publishing Company, 1990), 360 


\section{Missio Ecclesiae, 5(2), Oktober 2016, 102-133}

(bnd Ul 19:15b). ${ }^{42}$ Pengutusan dua-dua orang adalah untuk saling membantu dalam pelayanan (bnd Mark 6:7 dan Kis 8:14 (Petrus dan Yohanes); 13:2 (Barnabas dan Saulus); 15:40 (Paulus dan Silas). ${ }^{43}$

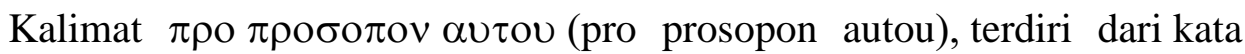
$\pi \rho \mathrm{o}$ (pro) yang berarti sebelum, dihadapan. ${ }^{44}$ Kata $\pi \rho \circ \sigma o \pi \mathrm{ov}$ (prosopon; kata benda, genetif, tunggal), ${ }^{45}$ artinya surface, face, ${ }^{46}$ bisa juga diterjemahkan mendahului. Terjemahan NIV dan NASB ahead (mendahului) seperti halnya yang diterjemahkan oleh LAI. Robert Stein menjelaskan kata ini demikian:

A head of him, literally before his face. This literally tie with the preceding material (9:52-53) is also the exact expression used in 7:27 (cf. Acts 13:24) for Jhon the Baptist mission. After the death of Jhon the Babtist, the twelve (Luke 9:25) and the seventy (-Two) (10:1) took up the task of preparing the way for the Lord. ${ }^{47}$

Pernyataan di atas menjelaskan bahwa kata a head of him berhubungan dengan bagian-bagian sebelumnya (9:52-53), yakni misi Yohanes Pembaptis. Setelah kematian Yohanes Pembaptis, tugas itu dilanjutkan oleh dua belas murid dan tujuh puluh murid, untuk mempersiapkan jalan bagi Tuhan. Hal yang serupa diungkapkan Boland bahwa: "Menurut Lukas, mereka diutus untuk menyiapkan kedatangan Yesus sendiri". ${ }^{8}$ Dengan demikian dapat disimpulkan bahwa alasan Tuhan Yesus mengutus para murid adalah untuk mendahului-Nya dengan maksud mempersiapkan jalan bagi Dia yakni pelayanan-Nya. Kata berikutnya adalah $\pi \mathrm{o} \lambda \mathrm{\imath}$ (polin) yang diterjemahkan city, town, capital city. ${ }^{49}$ Kata $\tau$ o $\pi \mathrm{ov}$ (topon) yang berarti tempat (di kota, desa, bangunan, dll), ${ }^{50}$ yang tidak memiliki batasan sehingga dapat berarti di desa atau dikota. Yesus mengutus para murid untuk mendahului-Nya ke setiap kota dan desa yang akan

${ }^{42}$ B. J. Boland, Boland, Tafsiran Alkitab Injil Lukas. Jakarta: BPK Gunung Mulia, 2001), 255

${ }^{43}$ Robert Stein, The New American Commentary Luke Vol 24. (NashvilleTennessee: Broadman Press, 1990), 304

${ }^{44}$ Barclay Newman, Kamus Yunani..., 139

${ }^{45}$ Barbara dan Timothy, Analytical Greek..., 216

${ }^{46}$ Horst Balz dan Gerhard Schneider, Exegetical Dictionary..., 180

${ }^{47}$ Robert H. Stein, The New American ..., 304

${ }^{48}$ B. J. Boland, Tafsiran Alkitab..., 255

${ }^{49}$ Horst Balz, Exegetical Dictionary..., 129

${ }^{50}$ Hasan Sutanto, Perjanjian Baru..., 681 
Dia kunjungi. Pelayanan yang dilakukan oleh Yesus tidak terbatas pada suatu tempat tertentu, tetapi di semua tempat dan kepada semua orang.

\section{Tuaian Banyak, Pekerja Sedikit (ay. 2)}

Kata $\theta \varepsilon \rho ı \sigma \mu o \varpi$ (therismos) yang bisa diterjemahkan dengan harvest. ${ }^{51}$ Howard Marshall menjelaskan: " $\theta \varepsilon \rho 1 \sigma \mu о \varpi$ is harvest, the crop to be harvested (Rev 14:15) or the process (or time) of harvesting (Mt. 13:30,39; Mk 4:29; Jn 4:35)". 52 Robert Stein juga menjelaskan:

It would have been understood as being much larger by Luke and his readers than by the seventy (two) who actually went on the mission because Luke and his readers would have understood this as involving a mission to the whole world (cf. 24:47; Act 1:8). This harvest is not to be confused with the final harvest "on that day" (Luke 10:12-15; cf. Matt 13:24-30, 36-43; Rev 14:15-16) but refers to the present harvest of believers in the "now" time (John 4:35). ${ }^{53}$

Pernyataan di atas menjelaskan bahwa harus dimengerti secara luas baik Injil Lukas dan pembacanya bahwa tugas tujuh puluh murid secara nyata pergi untuk pelayanan misi karena pelayanan misi adalah untuk seluruh dunia. Panenan bukan saja nanti pada hari akhir, namun mengacu pada waktu sekarang ini.

Kata $\pi \mathrm{o} \lambda \nu \varpi$ (polus; kata sifat, nominatif, maskulin, tunggal) yang diterjemahkan much, many. ${ }^{54}$ NASB dan NIV menterjemahkan plentiful (berlimpah-limpah), yang menunjukkan jumlah dari hasil panen yang sangat banyak.

${ }^{51}$ Horst Balz dan Gerhard, Exegetical Dictionary..., 144

${ }^{52}$ Howard Marshall, New International Greek Testament Commentary On Lukas, (Grand Rapids: Wm. B. Eerdmans Publishing Co, 1989), 416

${ }^{53}$ Robert Stein, The New American Commentary..., 304

${ }^{54}$ Horst Balz dan Gerhard, Exegetical Dictionary..., 131 
Kata $\varepsilon \rho \gamma \alpha \tau \alpha \imath$ (ergatai; kata benda, nominatif, maskulin, jamak) ${ }^{55}$ yang

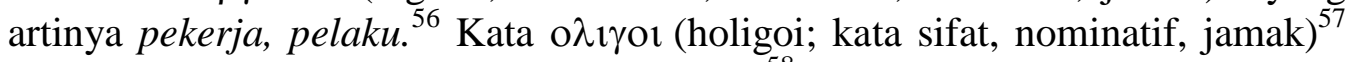
artinya sedikit, beberapa, sejumlah kecil. ${ }^{58}$ LAI, KJV, NASB dan LAI menerjemahkan dengan "few" (sedikit). Kata ini menunjuk pada jumlah pekerja yang bekerja untuk hasil panen, yang jumlahnya tidak sebanding dengan jumlah panen yang berlimpah.

Kata $\delta \varepsilon \eta \theta \eta \tau \varepsilon$ (deethete; kata kerja, aorist, imperatif, pasif, orang ke 2 jamak) ${ }^{59}$ dari kata dasar $\delta \varepsilon \circ \mu \alpha \imath$ (deomai) yang bisa diterjemahkan to pray, to ask someone for something, ${ }^{60}$ (berdoa, mohon, minta sesuatu kepada seseorang. ${ }^{61}$ Bentuk imperatif adalah suatu perintah, dengan demikian kata ini dapat diartikan "mintalah, berdoalah". Ini merupakan perintah atau dorongan Tuhan Yesus kepada murid-muridNya untuk berdoa atau meminta kepada

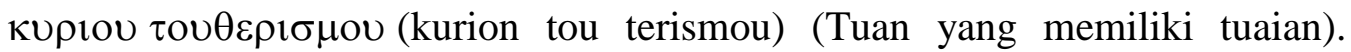
Selain mereka diutus, ketujuh puluh murid pertama-tama didorong untuk berdoa supaya banyak orang yang akan menjadi pekerja dalam memberitakan Injil. ${ }^{62}$ Usaha misi tidak hanya berupa usaha di ladang misi, tetapi juga berupa doa serta pimpinan Allah yang berkuasa. ${ }^{63}$ Jadi dapat disimpulkan bahwa selain pergi untuk memberitakan Injil, para murid diperintahkan untuk berdoa, supaya Tuhan mengirim pekerja untuk tuaian yang besar.

\section{Situasi Yang Akan Dihadapi Para Murid (ay. 3)}

Kata $\cup \pi \alpha \gamma \varepsilon \tau \varepsilon$ (hypagete; present, imperatif, aktif, orang ke 2 tunggal) ${ }^{64}$ dari kata dasar $v \pi \alpha$ yo (hypago) yang diterjemahkan to go, to go fort ${ }^{65}$ artinya

${ }^{55}$ Barbara dan Timothy, Analytical Greek..., 216

${ }^{56}$ Hasan Sutanto, Perjanjian Baru..., 312

${ }^{57}$ Barbara dan Timothy, Analytical Greek..., 216

${ }^{58}$ Barclay Newman, Kamus Yunani..., 116

${ }^{59}$ Barbara dan Timothy, Analytical Greek..., 216

${ }^{60}$ Fritz Rienecker, A Liguistic Key..., 169

${ }^{61}$ Barclay Newman, Kamus Yunani..., 37

${ }^{62}$ B. J. Boland, Tafsiran Alkitab..., 256

${ }^{63}$ Darell Bock, Baker Exegetical Commentary On The New Testament Luke Vol 2 , (Grand Rapids, Michigan: A Division Of Baker Book House Co, 1996), 994

${ }^{64}$ Barbara dan Timothy, Analytical Greek..., 216

${ }^{65}$ Frits Rienecker, A Linguistic Key..., 168 


\section{Missio Ecclesiae, 5(2), Oktober 2016, 102-133}

pergi, berangkat. ${ }^{66}$ Imperatif menunjukkan suatu perintah atau dorongan, sehingga kata ini dapatlah diartikan pergilah/berangkatlah.

Kata 1 oov (idou; demonstratif particle), ${ }^{67}$ partikel yang bersifat demonstratif, yang diterjemahkan "lihatlah" atau "sesungguhnya", yang memberi penekanan kepada kalimat sesudah kata itu.

Kata $\alpha \rho v \alpha \varpi$ (arnas; kata benda, akusatif, jamak) ${ }^{68}$ yang diterjemahkan $\operatorname{lambs}^{69}$ (domba yang masih kecil). Domba adalah binatang jinak yang bersih, tidak merusak atau merugikan, tetapi bersifat agak dungu yang justru merupakan makhluk yang mudah dimangsa dan tersesat. ${ }^{70}$ Murid-murid digambarkan seperti domba-domba yang lemah dan harus bergantung kepada Allah. $^{71}$

Kata $\lambda u \kappa \omega v$ (lukon; kata benda genetif, jamak) ${ }^{72}$ yang diterjemahkan dengan "serigala," di mana penyebutannya dalam seluruh Alkitab hanyalah metaforis, mengacu kepada seorang yang menyalahgunakan wibawanya (Zef $3: 3)^{73}$

Gambaran anak domba dan serigala adalah sangat terkenal di kalangan orang Yahudi dan bangsa-bangsa lain di zaman dahulu kala. Serigala merupakan gambaran binatang-binatang buas yang berbahaya atau lawan yang akan mengancam pemberita-pemberita Injil. Dalam ayat 3 ini lebih ditekankan bahaya dan ancaman yang akan dialami oleh murid-murid Yesus. Namun perkataan ini juga dimaksudkan sebagai penghiburan, bahwa di tengah-tengah bahaya dan ancaman ada gembala yang akan memelihara mereka, yaitu Tuhan Yesus. $^{74}$

\section{Beberapa Instruksi Bagi Para Murid (ay. 4-12)}

Dalam ayat 4-12 Yesus memberikan beberapa instruksi ketika mereka hendak berangkat ke ladang misi dan ketika mereka berada di ladang misi.

${ }^{66}$ Barclay Newman, Kamus Yunani..., 177

67 Joseph H Thayer, Thayer's Greek English Lexicon Of The New Testament, (Hendrickson Publishers Inc, 2000), 297

${ }^{68}$ Barbara dan Timothy, Kamus Yunani..., 216

${ }^{69}$ Horst Balz dan Gerhard, Exegetical Dictionary..., 72

70 __ Ensiklopedi Alkitab Masa Kini Jilid I, (Jakarta: Yayasan Komunikasi Bina Kasih/OMF, 2002), 254-255

${ }^{71}$ Frank Gaebelein, The Expositors Bible ..., 937

${ }^{72}$ Barbara dan Timothy, Analytical Greek..., 216

$73 \ldots$ Ensiklopedi Alkitab Jilid I..., 386I

${ }^{74}$ B. J. Boland, Tafsiran Alkitab..., 256 


\section{Instruksi agar tidak membawa bekal (ay.4)}

Kata $\beta \alpha \lambda \lambda \alpha v \tau \iota$ v (balantion; kata benda, akusatif, tunggal) ${ }^{75}$ yang diterjemahkan dengan purse ${ }^{76}$ artinya pundi-pundi, kantung uang, dompet. ${ }^{77}$ Kata ini ditulis sesudah kata bastazete, dengan demikian menunjukkan suatu larangan untuk tidak membawa bekal uang.

Kata $\pi \eta \rho \alpha \nu$ (peran; kata benda, akusatif, jamak) ${ }^{78}$ yang diterjemahkan dengan tas (milik penjelajah atau pengemis) ${ }^{79}$ yang merupakan suatu kantong pelancong atau ransel. Itu berarti para murid tidak boleh membawa tas (berisi bekal makanan, atau banyak pakaian) dalam perjalanan.

Kata berikut adalah $v 0 \pi \mathrm{o} \delta \eta / \mu \alpha \tau \alpha$ (upodemata; kata benda, akusatif, jamak) ${ }^{80}$ yang memiliki pengertian alas kaki ${ }^{81}$, NIV dan LAI menerjemahkan dengan sandal. Sandal merupakan sesuatu yang penting untuk digunakan ketika bepergian, terutama dalam perjalanan ke Palestina $(9: 3){ }^{82}$ Perintah Tuhan Yesus untuk tidak membawa pundi-pundi, tas dan sandal bermaksud supaya murid-murid tidak dibebani dengan banyak bekal yang bersifat jasmani, tetapi harus bersandar pada pertolongan Tuhan atas setiap kebutuhan jasmani mereka. Misi harus ditandai oleh doa dan ketergantungan penuh kepada Tuhan. ${ }^{83}$

Dapatlah disimpulkan bahwa utusan-utusan Tuhan tidak usah menyusahkan diri tentang makanan, minuman dan pakaian atau barang-barang yang lain. Memberitakan Injil adalah hal yang lebih penting untuk dilaksanakan. Para utusan Tuhan tidak perlu kuatir dengan kebutuhan pada waktu mengadakan perjalanan penginjilan karena Tuhan Yesus akan selalu menolong.

Kata $\mu \varepsilon \delta \varepsilon v \alpha$ (medena) artinya no one, not one, no man, nothing (tak seorangpun, tak seorang manusiapun, tak satupun) ${ }^{84}$ Kata berikutnya adalah $\alpha \sigma \pi \alpha \sigma \eta \theta \varepsilon$ (aspasethe; kata kerja, aorist, subjuntif, orang ke 2 jamak) ${ }^{85}$ dari

\footnotetext{
${ }^{75}$ Barbara dan Timothy, Analytical Greek..., 216

${ }^{76}$ Fritz Rienecker, A Linguistic Key..., 169

${ }^{77}$ Barclay Newman, Kamus Yunani..., 28

${ }^{78}$ Barbara dan Timothy, Analytical Greek..., 216

${ }^{79}$ Barclay Newman, Kamus Yunani..., 133

${ }^{80}$ Barbara dan Timothy, Analytical Greek..., 216

${ }^{81}$ Hasan Sutanto, Perjanjian Baru..., 780

${ }^{82}$ Darrell L. Bock, Baker exegetical Commentary ..., 997

${ }^{83}$ Darrell L. Bock, Baker exegetical Commentary ..., 997

${ }^{84}$ Joseph H. Thayer, Thayer'snGreek English Lexicon ..., 411

${ }^{85}$ Barbara dan Timothy, Analytical Greek..., 216
} 
kata dasar $\alpha \sigma \pi \alpha \chi \omega$ (aspazo) yang diterjemahkan to greet $^{86}$ memiliki pengertian bersalam, menyampaikan salam kepada. ${ }^{87}$ Larangan untuk tidak memberi salam dalam perjalanan bukanlah diterjemahkan suatu ketidaksopanan, tetapi memberi salam akan memakan waktu lebih lama. ${ }^{88}$ Boland mengemukakan bahwa:

Di tengah jalan tidak usah mereka "memberi salam" kepada siapapun (bnd. 2 Raj 4:29). Sebab "memberi salam" berarti berhenti berjalan, saling menanya "dari mana mau kemana" serta meluangkan waktu untuk bercakap-cakap, biasanya tentang hal-hal yang tidak penting. ${ }^{89}$

\section{Instruksi agar memberi salam kepada tuan rumah (ay. 5-6)}

Kata $\lambda \varepsilon \gamma \varepsilon \tau \varepsilon$ (legete; kata kerja, aorist, imperatif, aktif, orang ke 2 jamak) ${ }^{90}$ dari kata dasar $\lambda \varepsilon \gamma \omega$ (lego), ${ }^{91}$ artinya berkata, berbicara, mengucapkan. Dalam bentuk imperatif sehingga dapatlah diartikan katakanlah. Kata berikutnya Eıрๆ $\eta$ (eirene) artinya peace ${ }^{92}$ (damai sejahtera). Damai sejahtera merupakan salam yang terkenal di kalangan orang Yahudi. ${ }^{93}$ Yesus menginstruksikan kepada murid-murid-Nya bahwa salam damai sejahtera merupakan hal yang penting untuk disampaikan ketika mereka masuk ke suatu kota atau rumah untuk mencari tempat yang akan mereka tinggal. Salam damai sejahtera yang disampaikan dapat diterima dan ditolak, yang dapat dilihat pada ayat selanjutnya. $^{94}$

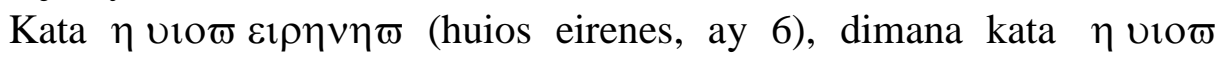
(huios) artinya anak, anak laki-laki, anak (binatang), pengikut, keturunan, rakyat, ${ }^{95}$ yang dalam konteks ayat ini lebih tepat diterjemahkan anak. Maka

${ }^{86}$ Fritz Rienecker, A Linguistic Key..., 168

${ }^{87}$ Barclay Newman, Kamus Yunani..., 24

${ }^{88}$ Robert Stein, The New American ..., 305

${ }^{89}$ B.J Boland, Tafsiran Alkitab..., 257

${ }^{90}$ Barbara dan Timothy, Analytical Greek..., 216

${ }^{91}$ Barclay Newman, Kamus Yunani..., 99

${ }^{92}$ Horst Balz dan Gerhard, Exegetical Dictionary..., 394

${ }^{93}$ Darell L. Bock, Baker Exegetical..., 997

${ }^{94}$ Frank Gaebelein, The Expositor's Bible commentary..., 937

${ }^{95}$ Hasan Sutanto, Perjanjian Baru..., 770 
kata huios eirenes dapat diterjemahkan dengan a man of peace, ${ }^{96}$ adalah orang yang berespon terhadap salam damai yang disampaikan murid-murid. ${ }^{97}$

Kata berikut adalah $\varepsilon \pi \alpha v \alpha \pi \alpha \eta \sigma \varepsilon \tau \alpha \mathrm{l}$ (epanapaesetai; kata kerja, futurum, indikatif, aktif, tunggal, ${ }^{98}$ dari kata $\alpha \pi \alpha v \alpha \pi \alpha v o \mu \alpha \imath$ (apanapauomai) yang diterjemahkan dengan to rest upon, ${ }^{99}$ artinya tetap, bersandar. ${ }^{100}$ Karena kata ini dalam bentuk futurum yang menunjukkan pada masa depan, maka dapatlah diartikan akan tetap bersandar. Jadi maksud kalimat ini adalah bahwa salam damai dari murid-murid akan menjadi milik orang yang menerima salam itu.

Kata $\alpha v \alpha \kappa \alpha \mu \psi \varepsilon \imath$ (anakampsei; kata kerja, futurum, indikatif, aktif, orang ke 3 tunggal). ${ }^{101}$ Bentuk futurum $\alpha v \alpha \kappa \alpha \mu \pi \tau \omega$ (anakampto) diterjemahkan dengan to return, ${ }^{102}$ kembali, pulang, berbalik. ${ }^{103}$ Dalam ayat ini kata ini tepat diterjemahkan dengan akan kembali atau akan berbalik.

Dapat disimpulkan ayat enam ini menunjukkan bahwa apabila orang menerima damai sejahtera para murid, maka damai sejahtera tersebut akan terus bersama dia. Namun jika dia menolak, maka damai sejahtera itu akan kembali kepada yang menyampaikannya (para murid Tuhan Yesus).

\section{Instruksi agar bersedia menerima penyambutan tuan rumah (ay. 7-8)}

Kata $\mu \varepsilon v \varepsilon \tau \varepsilon$ (menete; present, imperatif, aktif) ${ }^{104}$ dari kata dasar $\mu \varepsilon v \omega$ (meno) yang diterjemahkan to remain ${ }^{105}$ (tinggal). Bentuk imperatif kata ini dapat diterjemahkan tinggallah. Terjemahan yang sama diikuti oleh NASB dan LAI, sedangakan NIV dan KJV memakai kata stay (tetap). Kata berikut adalah $\varepsilon \sigma \theta 10 v \tau \varepsilon \varpi$ (esthiontes; kata kerja, present, partisip (imperatif sense), aktif) ${ }^{106}$ yang artinya makanlah. ${ }^{107}$ Kata $\pi$ ivov $\tau \varepsilon \varpi$ (pinontes; present partisip (imperatif

\footnotetext{
96 1994), 998 , New Bible Commentary 21 Century dition, (England: Inter- Varsity Press,

${ }^{97}$ Darrell L. Bock, Baker Exegetical..., 998

${ }^{98}$ Barbara dan Timothy, Analytical Greek..., 217

${ }^{99}$ Fritz Rienecker, A Linguistic Key..., 169

${ }^{100}$ Hasan Sutanto, Perjanjian Baru..., 294

${ }^{101}$ Barbara dan Timothy, Analytical Greek..., 217

${ }^{102}$ Fritz Rienecker, A Linguistic Key..., 169

${ }^{103}$ Barclay Newman, Kamus Yunani..., 10

${ }^{104}$ Barbara dan Timothy, Analytical Greek..., 217

${ }^{105}$ Fritz Rienecker, A Linguistic Key..., 169

${ }^{106}$ Barbara dan Timothy, Analytical Greek..., 217

${ }^{107}$ Barclay Newman, Kamus Yunani..., 67
} 


\section{Missio Ecclesiae, 5(2), Oktober 2016, 102-133}

sense), aktif, nominatif) ${ }^{108}$ artinya to drink, ${ }^{109}$ minumlah. Bentuk Partisip kata ini artinya bahwa hal tersebut dilakukan pada waktu yang sama dengan apa yang disebut dalam kata kerja induk kalimat. Hal ini berarti perintah untuk tinggal bagi murid-murid merupakan juga perintah untuk makan dan minum ditempat yang mereka tempati.

Dalam konteks ini, upah adalah keramatamahan atau kesediaan tuan rumah menerima tamu dengan memberi makanan dan tempat tinggal. ${ }^{110}$ Para pemberita Injil tidak usah segan waktu menerima pemberian berupa penginapan dan makanan dalam rumah yang mereka kunjungi, karena para pekerja layak menerima upah dari setiap pekerjaannya.

Kata berikut adalah $\mu \varepsilon \tau \alpha \beta \alpha 1 / v \varepsilon \tau \varepsilon$ (metabainete; present, imperatif, aktif, orang ke 2 jamak) ${ }^{111}$ dari kata dasar $\mu \varepsilon \tau \alpha \beta \alpha 1 / v \omega$ (metabaino) yang dapat diterjemahkan dengan to change a place, to leave, to depart, ${ }^{112}$ berpindah tempat, meninggalkan, menyimpang. Wiliam Hendriksen mengartikan kata ini to go or move from one place to another. ${ }^{113}$ Berdasarkan bentuknya kata ini dapat diterjemahkan janganlah berpindah-pindah.

Penekanan bahwa "pekerja layak menerima upah" didasari dari kenyataan yang ada dalam Perjanjian Lama dan tradisi Yahudi (Im 19:13; Ul 24:14-15; Mal 3:5), di mana mereka lebih sering berbuat kesalahan atau kejahatan yaitu tidak memberi atau tidak membayar upah harian para pekerja yang seharusnya mereka bayar pada hari itu juga. ${ }^{114}$

Kata $\delta \varepsilon \chi \omega \nu \tau \alpha \iota$ (dechontai; present, subjuntif, middle, ${ }^{115}$ dari kata dasar $\delta \varepsilon \chi 0 \mu \alpha 1$ (dexomai) yang dapat diterjemahkan dengan to receive, to welcome, ${ }^{116}$ berdasarkan bentuknya kata ini dapat diterjemahkan dengan mereka menerima. Kata berikut adalah $\pi \alpha \rho \alpha \tau \imath \theta \varepsilon \mu \varepsilon v \alpha$ (paratithemena; present, participle, pasif,

${ }^{108}$ Barbara dan Timothy, Analytical Greek..., 216

109 Joseph H Theyer, Thayer's Greek English..., 511

${ }^{110}$ Darell L. Bock, Baker exegetical..., 999

${ }^{111}$ Barbara dan Timothy, Analytical Greek..., 217

${ }^{112}$ Fritz Rienecker, A Linguistic Key..., 169

113 Wiliam Hendriksen, New Testament Commentary Luke, (Endinburgh: The Banner Of Truth Trust, 1978), 587

${ }^{114}$ Darell Bock, Baker Exegetical Commentary..., 999

${ }^{115}$ Barbara dan Timothy, Analytical Greek..., 217

${ }^{116}$ Fritz Rienecker, A Linguistic Key..., 169 
nominatif, jamak) ${ }^{117}$ dari kata kerja $\pi \alpha \rho \alpha \imath \imath \theta \varepsilon \mu \imath$ (paratithemi) yang artinya to set (food) before someone, ${ }^{118}$ menghidangkan makanan di depan seseorang. ${ }^{119}$

Dalam ayat delapan ini tidak lagi dibicarakan tentang rumah tetapi tentang kota, menunjuk pada tempat yang lebih terbuka/umum, di mana pemberita Injil tidak saja hadir secara diam-diam tetapi di depan umum dengan resiko bahwa para murid harus juga bersedia makan jenis makanan apa pun yang dihidangkan kepada mereka. Boland mengemukakan juga bahwa:

Perkataan "makanlah apa yang dihidangkan kapadamu" tampaknya menyerupai apa yang ditulis dalam ayat 7. Tetapi jika Lukas dalam hal ini mengingat kepada pemberita Injil seperti yang terjadi kemudian dalam dunia bangsa-bangsa, maka bolehlah keterangannya sebagai berikut juga: dalam menerima undangan semacam itu tidak usah orang memikirkan apakah makanan itu "najis/haram" atau "tidak najis/halal' menurut undang-undang agama Yahudi (lih I Kor 10:27; ingat kepada Petrus, yang sukar memahami hal itu: Kis 10:9 dst dan Gal $2: 11 \mathrm{dst}$ ).

Hal ini seharusnya menjadi sikap para pemberita Injil ketika mereka diterima disuatu kota. Darell Bock juga mengemukakan bahwa:

Instruksi agar memberitakan bahwa Kerajaan Allah sudah dekat (ay. 9) Kata $\theta \varepsilon \rho \alpha \pi \varepsilon v / \varepsilon \tau \varepsilon$ (therapeuete; present, imperatif, aktif) ${ }^{120}$ dari kata kerja dasar $\theta \varepsilon \rho \alpha \pi \varepsilon \cup \omega$ (therapeuo) artinya to treat medically, to heal ${ }^{121}$ (menyembuhkan). ${ }^{122}$ Dalam bentuk Imperatif, artinya sembuhkanlah. Boland mengemukakan bahwa: sama seperti "kedua belas orang" itu, "ketujuh puluh orang" ini mendapat juga karunia untuk menyembuhkan orang-orang sakit dalam nama Yesus, yakni sebagai wakil yang dikuasakan penuh (ay 9; bnd ay. 17 dan 9:1). ${ }^{123}$ Robert Stein mengemukakan bahwa: "Luke may have placed healing first because such healing are to be understood as signs that God's kingdom has come (cf 11:20). In Mat 10:8 there is a more comprehensive

\footnotetext{
${ }^{117}$ Barbara dan Timothy, Analytical Greek..., 217

${ }^{118}$ Fritz Rienecker, A Linguistic Key..., 169

119 Barclay Newman, Kamus Yunani..., 125

${ }^{120}$ Barbara dan Timothy, Analytical Greek..., 217

${ }^{121}$ Fritz Rienecker, A Linguistic Key..., 169

${ }^{122}$ Barclay Newman, Kamus Yunani..., 77

${ }^{123}$ B. J. Boland, Tafsiran Alkitab..., 258
} 


\section{Missio Ecclesiae, 5(2), Oktober 2016, 102-133}

description of the mission."124 Pernyataan ini menjelaskan bahwa Lukas menempatkan penyembuhan di awal perintah karena penyembuhan dapat dipahami sebagai tanda bahwa Kerajaan Allah sudah datang.

Kata berikut adalah $\eta \gamma \gamma\left(\kappa \varepsilon v\right.$ (eggiken; perfeck, indikatif, aktif, ${ }^{125}$ dari kata $\varepsilon \gamma \gamma \downarrow \chi \omega$ (eggizo) yang artinya to draw near (telah sangat dekat). Kata ini menunjuk pada kata berikutnya $\beta \alpha \sigma \imath \lambda \varepsilon \imath \alpha$ oo $\theta \varepsilon$ ov (basileia tou teou) (kerajaan Allah). Jadi hal ini berarti kerajaan Allah telah sangat dekat, sehingga ini harus diberitakan. Memberitakan Injil adalah memberitakan "Kerajaan Allah sudah dekat padamu". ${ }^{126}$ Maksud dari pemberitaan "Kerajaan Allah sudah dekat" adalah memberitakan tentang Kristus dan perbuatanNya, dari zaman Yesus sampai kedatangan-Nya yang kedua, seperti yang diungkapkan oleh Ridderbos dan Baarlink: 'Di dalam berita 'Kerajaan Sorga sudah dekat' terletak pusat gambaran masa depan yang besar, yang dilukiskan oleh Yesus dan meliputi seluruh 'masa kini' dari zaman Yesus sampai pada parousia-Nya.",127

\section{Instruksi agar tahu apa yang harus dilakukan Jika Ditolak (ay. 10-12)}

Kata $\delta \ni$ (de; kata penghubung), ${ }^{128}$ memiliki pengertian tetapi, dan, adapun, lalu, maka, sebab, yakni, melainkan, walaupun, kini, pada waktu itu. ${ }^{129}$ Dalam konteks ayat ini, kata de lebih tepat diterjemahkan dengan tetapi. Kata ini merupakan kata penghubung yang menghubungkan ayat 9 dan 10, yang menunjuk pada hal-hal yang harus dilakukan oleh murid-murid pada waktu mereka ditolak.

Kalimat $\mu \varepsilon \delta \varepsilon \chi \omega \nu \tau \alpha \iota$ (me dechontai) terdiri dari kata $\mu \varepsilon$ (me; kata sifat, kata keterangan) ${ }^{130}$ memiliki pengertian $t_{i d a k^{131}}$. Kata $\delta \varepsilon \chi \omega \nu \tau \alpha \iota$ (dechontai; subjantif, present, aktif) yang diterjemahkan take, receive ${ }^{132}$, memiliki

${ }^{124}$ Robert Stein, The New American..., 306

${ }^{125}$ Barbara dan Timothy, Analytical Greek..., 217

${ }^{126}$ B. J. Boland, Tafsiran Alkitab..., 258

${ }^{127}$ H. Ridderbos dan Baarlink, Pemberitaan Yesus Menurut Injil-Injil Sinoptis, (Jakarta: BPK Gunung Mulia, 1975), 225

${ }^{128}$ Barbara dan Timothy, Analytical Greek..., 217

${ }^{129}$ Hasan Sutanto, Perjanjian Baru..., 783

${ }^{130}$ Barbara dan Timothy, Analytical Greek..., 217

${ }^{131}$ Barclay Newman, Kamus Yunani..., 107

${ }^{132}$ Horst Balz dan Gerhard, Exegetical Dictionary..., 292 


\section{Missio Ecclesiae, 5(2), Oktober 2016, 102-133}

pengertian menerima ${ }^{133}$. Dari bentuknya kata ini dapat diterjemahkan mereka menerima. Jadi me dechontai memiliki pengertian mereka tidak menerima.

Kata $\varepsilon \chi \varepsilon \lambda \theta 0 \nu \tau \varepsilon \varpi$ (exelthontes; aorist, partisip (imperatif sense), aktif) ${ }^{134}$ dari kata $\varepsilon 0 \chi \varepsilon / \rho \xi o \mu \alpha \imath$ (exerchomai) yang diterjemahkan to go out (pergi keluar). ${ }^{135}$ Bentuk Partisip kata ini artinya bahwa hal tersebut dilakukan pada waktu yang sama, berarti ketika para murid tidak diterima, pada waktu itu juga mereka harus pergi keluar.

Kata $\alpha \pi \circ \mu \alpha \sigma \sigma o \mu \varepsilon \theta \alpha$ (apomassometha; present, indikatif middle) ${ }^{136}$ dari kata $\alpha \pi \circ \mu \alpha \sigma \sigma o \mu \alpha \mathrm{l}$ (apomassomai) yang diterjemahkan to wipe of, to rub off ${ }^{137}$ yang memiliki pengertian menghapuskan, menyeka diri. ${ }^{138}$ Bentuk present indikatif middle menunjukkan bahwa melakukan sesuatu yang berakibat pada orang lain, juga berakibat pada diri sendiri. Mengebaskan kaki artinya diri sendiri tidak bertanggung jawab atas keputusan orang yang menolak pemberitaannya. Dilihat dari bentuknya maka kata ini dapat diterjemahkan dengan kami sekakan, hapuskan. Hal ini sesuai dengan adat Yahudi, sebagai peringatan bagi penduduk setempat, dan artinya sebagai kesaksian yang memberatkan kesalahan mereka, yakni sebagai tanda yang akan membuktikan kesalahan mereka pada hari penghukuman yang akan dilakukan oleh Allah. Peringatan itu ditandai dengan mengebaskan debu dari kaki, yang bagi orang Yahudi sebagai tanda bahwa hubungan dengan orang tersebut telah putus. Kebiasaan bagi orang Yahudi apabila rabi-rabi Yahudi masuk kembali ke negeri Yahudi setelah pulang dari luar negeri waktu diperbatasan mereka harus mengebaskan debu dari kaki dan pakaian mereka. ${ }^{139}$ Hal ini menunjukkan bahwa apabila orang itu mati dalam dosanya, tanggungjawab terhadap dosanya bukan lagi tanggungjawab hamba Tuhan, tetapi merupakan tanggung jawab orang tersebut.

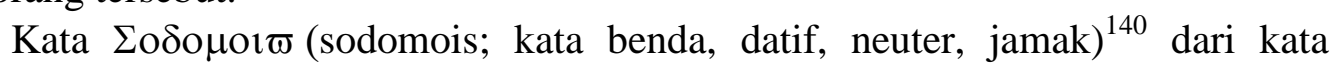
$\Sigma o \delta o \mu \alpha$ (sodoma) yang berarti Sodom. ${ }^{141}$ Melihat dari bentuknya dapat

\footnotetext{
${ }^{133}$ Barclay Newman, Kamus Yunani..., 37

${ }^{134}$ Barbara dan Timothy, Analytical Greek..., 217

${ }^{135}$ Fritz Rienecker, A Linguistic Key..., 169

${ }^{136}$ Barbara dan Timothy, Analytical Greek..., 217

${ }^{137}$ Fritz Rienecker, A Linguistic Key..., 169

${ }^{138}$ Barclay Newman, Kamus Yunani..., 20

${ }^{139}$ B. J. Boland, Tafsiran Alkitab..., 214

${ }^{140}$ Barbara dan Timothy, Analytical Greek..., 217

${ }^{141}$ Hasan Sutanto, Perjanjian Baru..., 711
} 
diterjemahkan bagi Sodom. Sodom adalah kota yang dimusnahkan Allah dengan api dan belerang karena kebobrokan atau kejahatannya. ${ }^{142}$

Istilah $\eta \mu \varepsilon \rho \alpha \varepsilon \kappa \varepsilon i v \eta$ (hemera ekeine) memiliki pengertian hari itu. Balz menjelaskan bahwa kata itu menunjuk kepada hari penghakiman. ${ }^{143}$ Hal yang sama juga dikemukakan oleh Robert Stein bahwa: "This designates the final day of judgment"144 demikian pula pendapat John Nolland: "That day is the day of God's final judgment" 145

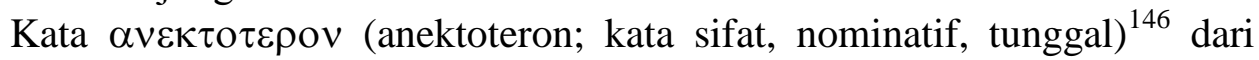
kata $\alpha v \varepsilon \kappa \tau \mathrm{\sigma} \varpi$ (anektos) yang artinya bearable, endurable, ${ }^{147}$ dapat ditahan. ${ }^{148}$ LAI menerjemahkan dengan akan lebih ringan tanggungannya. Ini menunjukkan bahwa hukuman Allah bagi kota yang tidak menerima para utusan Tuhan akan lebih berat daripada hukuman atas Sodom, sekalipun Sodom sudah dianggap sebagai contoh segala dosa dan kejahatan (bnd Kej 19). ${ }^{149}$ vJadi dapatlah disimpulkan bahwa pada hari penghakiman Allah hukuman bagi kota yang menolak para pemberita Injil akan sangat berat.

\section{RELEVANSI LUKAS 10:1-12 BAGI HAMBA TUHAN SEBAGAI PELAKSANA MISI ALLAH}

Pada bagian ini penulis akan memaparkan mengenai relevansi Lukas 10:1-12 bagi hamba Tuhan sebagai pelaksana misi Allah mencakup beberapa hal seperti berikut:

\section{Pentingnya Penetapan dan Pengutusan Tuhan}

Prinsip dasar dalam pekerjaan misi adalah keteladanan Kristus, yaitu pengutusan. Misi dimulai berdasarkan penetapan dan pengutusan Allah Bapa sendiri. Allah Bapa sendiri yang pertama mengutus Yesus Kristus sebagai misionaris ke dalam dunia ini, untuk menyelamatkan manusia dari dosa. Dengan pola seperti inilah Yesus menunjuk dan mengutus murid-murid-Nya

\footnotetext{
${ }^{142}$ Horst Balz dan Gerhard, Exegetical Dictionary..., 257

${ }^{143}$ Horst Balz dan Gerhard, Exegetical Dictionary..., 121

${ }^{144}$ Robert Stein, The New American ..., 306

145 John Nolland, Word Bible Commentary, (Dalas Texas : Word Book Publisher), 555

${ }^{146}$ Barbara dan Timothy, Analytical Greek..., 217

${ }^{147}$ Frits Rienecker, A Linguistic Key..., 169

${ }^{148}$ Barclay Newman, Kamus Yunani..., 12

${ }^{149}$ B. J. Boland, Tafsiran Alkitab..., 259
} 
untuk pergi menjalankan tugas misi di dalam dunia ini, sebagaimana dikatakan Tuhan Yesus: "Sama seperti Bapa mengutus Aku, demikianlah juga sekarang Aku mengutus kamu" (Yoh 20:21). ${ }^{150}$ Setiap pemberita Kabar Baik yang pergi melaksanakan tugas penginjilan adalah utusan-utusan Allah.

Tujuh puluh murid ditetapkan dan diutus oleh Tuhan Yesus untuk mengerjakan suatu tugas pemberitaan Kabar Baik. Murid-murid ini adalah orang-orang yang benar-benar datang dari Tuhan, artinya Tuhan sendirilah yang telah memilih, memanggil, menetapkan dan mengutus mereka. ${ }^{151}$ Yesus berkata, "Bukan kamu yang memilih Aku, tetapi Akulah yang memilih kamu. Dan Aku telah menetapkan kamu, supaya kamu pergi dan menghasilkan buah dan buahmu itu tetap, supaya apa yang kamu minta kepada Bapa dalam namaKu, diberikan-Nya kepadamu" (Yoh 15:16). Allah yang memilih dan yang mengutus hamba-hamba-Nya, Dialah yang akan membuat mereka sanggup untuk menjadi pelayan. Tuhan yang mempercayakan pekerjaanNya, Tuhan juga yang menolong para pekerja-Nya untuk menemukan, memakai dan mengembangkan karunia-karunia rohani. ${ }^{152}$ Hamba Tuhan yang diutus tidak mewakili dirinya atau orang lain untuk tugas pemberitaan Kabar Baik, tetapi mewakili Allah, suara Allah, dan nama Allah dalam pelayanan.

Tuhan bertanggungjawab terhadap orang-orang yang telah ditetapkan dan diutus-Nya untuk melakukan pekerjaan-Nya, memberitakan Kabar Baik. Barnabas dan Paulus dalam pelayanan bukan semata-mata diutus oleh jemaat Antiokhia, tetapi mereka diutus oleh Tuhan, demikian juga dengan para hamba Tuhan yang diutus melalui lembaga, merupakan utusan Tuhan, lembaga hanya merupakan sarana atau alat. ${ }^{153}$

\section{Pentingnya Kerjasama Dalam Tim Pelayanan}

Tujuh puluh murid yang diutus oleh Tuhan Yesus tidak diutus sendirisendiri, tetapi berdua-dua. Tuhan Yesus mengutus mereka berdua-dua, karena sesuai dengan aturan bahwa kesaksian dua orang berlaku dan dapat dipercaya (bnd. Ul 19:15b), ${ }^{154}$ juga dengan maksud supaya saling membantu dalam pelayanan. Robert Coleman dalam bukunya Rancana Agung Penginjilan menulis: "Tidak dapat disangkal bahwa rencana ini dimaksudkan untuk

${ }^{150}$ Bagus Surjantoro, Hati Misi, (Yogyakarta: ANDI, 2006), 50

${ }^{151}$ Frank Gabelein, The Expositor's Bible Commentary..., 937

${ }^{152}$ Leroy Eims, Penuai yang Diperlengkapi..., 106-107

153 Petrus Octavianus, Missio Dei, Pengutusan Allah, (Batu-Malang: Departemen Literatur YPPII, 1974), 54

${ }^{154}$ B. J. Boland, Tafsiran Alkitab Injil Lukas..., 255 
memberi kepada murid-murid-Nya hubungan persaudaraan yang dibutuhkan dalam tugas ini. Mereka akan saling membantu. Dalam menghadapi kesukaran yang tidak selalu dapat dihindarkan, mereka masih dapat saling menghibur". ${ }^{155}$ Pelayanan dalam bentuk tim sangat penting, seperti yang dikemukakan oleh Makmur Halim dalam bukunya Model-Model Penginjilan Yesus bahwa:

Penginjilan yang baik harus dilakukan dalam bentuk group atau "Tim penginjilan" (Luk 10:1-4). Mereka dapat bekerja sama dan saling mengisi kekurangan dan mendukung dalam kesulitan. "Tim penginjilan" akan menjadikan pelayanan misi menjadi lebih luas dan mudah untuk dijangkau jika dibandingkan pelayanan yang dilakukan oleh satu orang. Tim ini akan mempertinggi mutu pelayanan dan pengembangannya. ${ }^{156}$

Pelayanan tim dalam pemberitaan Kabar Baik akan lebih efektif. Bukan berarti bahwa melayani seorang diri merupakan hal yang keliru. Dalam tim pelayanan dapat saling mendukung, menguatkan, dan mendoakan satu sama lain, sehingga banyak orang akan dapat dicapai bagi Kerajaan-Nya. ${ }^{157}$

\section{Ladang Tuhan Membutuhkan Pekerja}

Ladang Tuhan sangat luas, sehingga membutuhkan pekerja yang banyak untuk mengerjakan tuaian tersebut, seperti yang dikatakan Tuhan Yesus: "Tuaian banyak, tetapi pekerja sedikit" (Luk 10:2a). Tuaian atau ladang pelayanan Tuhan di bumi masih cukup banyak untuk dikerjakan, namun persoalannya adalah pekerja yang mengerjakan sedikit. ${ }^{158}$ Pekerja-pekerja ialah mereka yang telah diurapi, dipanggil dan diperlengkapi oleh Roh Kudus, dan dipercayakan bersaksi bagi-Nya kemanapun Allah mengirimnya. ${ }^{159}$ Tuhan bekerja dalam hidup orang yang ditentukan-Nya untuk melakukan pelayanan misi, sehingga memiliki belas kasihan terhadap orang-orang yang masih terikat oleh dosa. Jika dibandingkan dengan jiwa-jiwa atau tuaian, maka tidaklah sebanding dengan jumlah yang melayani. Yesus mengajak murid-murid untuk

\footnotetext{
${ }^{155}$ Robert Coleman, Rencana Agung Penginjilan, (Bandung: Kalam Hidup, 1964), 64

${ }^{156}$ Makmur Halim, Model-Model Penginjilan Yesus, (Malang: Gandum Mas, 2003), 53

157 Ibid., 63

${ }^{158}$ Stephen Tong, Menjadi Pelayan Kristus, (Surabaya: Yakin, 1976), 37

${ }^{159}$ Leroy Eims, Penuai yang Diperlengkapi..., 17
} 
berdoa kepada Allah yang empunya ladang, supaya Ia mengirim pekerjapekerja untuk mengerjakan ladang tersebut. ${ }^{160}$

\section{Kesadaran dan Kesiapan Untuk Masuk}

Dalam Lingkungan yang Berbahaya

Murid-murid Tuhan diutus "seperti domba di tengah-tengah serigala" (Luk. 10:3). Yesus memperingatkan murid-murid-Nya bahwa tidak semua orang mau menerima berita Injil, dan bahwa kenyataan itu akan mengakibatkan murid-murid diperlakukan dengan tidak baik. ${ }^{161}$ B. J. Boland mengatakan bahwa dalam pelayanan akan timbul perlawanan dan permusuhan, di mana para lawan akan mengancam pemberita-pemberita Injil sebagai binatang-binatang buas yang berbahaya. ${ }^{162}$ Sepanjang sejarah gereja dapat dilihat bagaimana para murid Kristus mengalami bahaya penganiayaan, bahkan ancaman maut. Murid Kristus dengan berbagai tanda dan karakter yang amat positif dan baik, justru sering mengalami penganiayaan, penghinaan, ejekan, derita dan berbagai ancaman lainnya, bahkan harus mengalami kematian yang tragis, yaitu mati syahid dalam mempertahankan iman dan kebenaran Injil. ${ }^{163}$ Menjadi hamba Tuhan bukan mencari kenyamanan hidup, perlindungan dan fasilitas, sebaliknya hamba Tuhan harus siap menghadapi kesulitan.

Dalam bermisi, seorang hamba Tuhan harus siap untuk hidup penuh dengan tantangan dan kesulitan, meninggalkan keinginan untuk mendapatkan jaminan hidup yang nyaman dan aman, karena orang yang taat akan panggilan Tuhan akan mengalami penyertaan Tuhan dalam penyerahan hidupnya bagi Tuhan. Ini merupakan janji Tuhan bagi para hamba-Nya. ${ }^{164}$

\section{Sikap dan Karakter Hamba Tuhan}

Tuhan Yesus menginstruksikan kepada para murid-Nya, bahwa mereka harus bersedia menerima apa yang disediakan tuan rumah, baik makanan maupun tempat tinggal. Inilah sikap yang harus dimiliki hamba Tuhan dalam pelayanan, yang intinya adalah sikap rendah hati. Dengan sikap ini, maka hamba Tuhan akan mudah diterima di tempat pelayanan. Menurut Bagus Surjantoro, seorang utusan Tuhan harus memiliki karakteristik seorang nelayan,

${ }^{160}$ Makmur Halim, Misi, Diskusi, dan Doa, ...40,41

${ }^{161}$ Robert Colemen, Rencana Agung Penginjilan..., 62

162 B. J. Boland, Tafsiran Alkitab Injil Lukas ..., 256

${ }^{163}$ Eddy Frances, Murid Kristus Jilid Dua, (Jakarta: Yayasan Sinar Nusantara, 2006), 98

\footnotetext{
${ }^{164}$ Bagus Surjantoro, Hati Misi..., 71
} 
karena nelayan di berbagai tempat di dunia ini secara umum, memiliki karakteristik-karakteristik dasar yang juga diperlukan oleh seorang "penjala manusia", karakteristik itu adalah: Pertama hamba Tuhan harus memiliki fokus yang jelas, yaitu hanya berfokus pada jiwa-jiwa terhilang untuk diselamatkan. Kedua, hamba Tuhan harus terbiasa hidup sederhana, yaitu hidup dengan keperluan jasmani seperlunya. Ketiga, hamba Tuhan harus rajin, yaitu rajin dalam pekerjaan pemberitaan Injil. Keempat, senantiasa sabar, yaitu sabar dalam menghadapi tantangan dan penderitaan. Kelima, hidup oleh iman, yaitu mempertaruhkan seluruh kehidupan kepada Tuhan, berserah dan percaya total kepada-Nya. ${ }^{165}$ Hal-hal ini merupakan karakteristik dasar yang diperlukan menjadi utusan Injil, disamping perlengkapan yang lain yang diperlukan untuk bekerja di ladang Tuhan. Ketika berada di tengah-tengah lingkungan yang berbahaya, hamba Tuhan perlu bersikap "cerdik seperti ular dan tulus seperti merpati” (Mat 10:16). ${ }^{166}$ Hal ini juga menunjukkan bahwa hamba Tuhan harus berhikmat dalam menyampikan Kabar Baik, karena tanpa hikmat dalam penyampaian dan pelayanan akan banyak tempat dan orang yang menjadi lebih tertutup terhadap berita Injil. ${ }^{167}$

\section{Tugas Hamba Tuhan Memberitakan Kerajaan Allah}

Tuhan Yesus mengutus murid-murid untuk memberitakan Kerajaan Allah. Tuhan Yesus menekankan pentingnya tugas yang baru bagi mereka untuk memberitakan bahwa "Kerajaan Sorga sudah dekat". ${ }^{168}$ Ridderbos dan Baarlink mengemukakan dalam bukunya bahwa: "Setiap pengkhotbah, bahkan setiap saksi Kristus bertugas untuk menyerukan kepada sesamanya di seluruh dunia proklamasi Kristus yang berbunyi: "waktunya sudah genap; Kerajaan Allah sudah dekat. Bertobatlah dan percayalah kepada Tuhan"169. Injil merupakan ringkasan pekabaran seluruh Perjanjian Baru, berisikan Kerajaan Allah dan kedatangannya (Luk 4:43; 8:1; 16:16). Oleh sebab itu dapat dikatakan juga, bahwa istilah "Kerajaan Allah" itu menyangkut keseluruhan pemberitaan Yesus Kristus dan rasul-rasul-Nya, atau bahwa di dalam pemberitaan Kerajaan itu terkandung bentuk dan inti atau ungkapan yang khas daripada seluruh penyataan-Nya tentang Allah. ${ }^{170}$ Pemberitaan tantang Kerajaan Allah haruslah

\footnotetext{
${ }^{165}$ Bagus Surjantoro, Hati Misi..., 134-137

${ }^{166}$ Robert Colemen, Rencana Agung Penginjilan ..., 63

${ }^{167}$ Bagus Suryantoro, Hati Misi..., 85,86

${ }^{168}$ Robert Coleman, Rencana Agung Penginjilan ..., 61

${ }^{169}$ Ridderbos dan Baarlink, Pemberitaan Yesus Menurut Injil-Injil Sinoptik..., 5

${ }^{170}$ Ibid., 11
} 
disampaikan kepada semua orang, sehingga banyak orang yang mengenal Kristus dan karya-karya-Nya bagi dunia ini.

\section{Mentalitas Hamba Tuhan Jika Ditolak di Tempat Pelayanan}

Dalam pelayanan pemberitaan Kabar Baik, perlu disadari bahwa hamba Tuhan akan menghadapi tantangan atau bahaya. Terlebih dari pada itu, hamba Tuhan harus menyadari sepenuhnya bahwa setiap pemberitaannya tidak selalu akan diterima oleh pendengar, banyak orang juga akan menolak pemberitaannya. ${ }^{171}$ Oleh sebab hamba Tuhan harus mempersiapkan diri, mental dan iman yang kokoh untuk menghadapi segala kemungkinan. Memang hamba Tuhan harus menghadapi berbagai kendala karena manusia berdosa cenderung menolak Kabar Baik. Hamba Tuhan tidak perlu kecewa karena Allah yang empunya pelayanan tersebut telah mengalaminya hingga Ia mati di kayu salib. Hamba Tuhan yang ditolak di tempat pelayanan tidak boleh marah, patah semangat, apalagi meninggalkan tempat pelayanan, tetapi hamba Tuhan harus menyerahkan penolakan tersebut kepada Tuhan.

\section{SIMPULAN}

Pekerjaan misi yaitu membawa orang-orang berdosa untuk mengenal Tuhan Yesus merupakan tugas semua orang yang percaya kepada-Nya. Semua orang percaya mempunyai tugas dan tanggung jawab untuk memberitakan Injil, seperti yang diamanatkan Tuhan Yesus (Mat 28:18-20). Namun lebih khusus lagi Allah memanggil dan menetapkan orang-orang tertentu untuk mengerjakan tugas misi itu.

Dalam pekerjaan misi membutuhkan banyak pekerja, karena ladang misi sangat luas. Pekerja yang dibutuhkan adalah hamba Tuhan yang memiliki beban misi untuk memenangkan sebanyak mungkin jiwa bagi kemuliaan Tuhan.

Hamba Tuhan perlu memahami misi sehingga dapat terlibat dalam pelayanan misi. Injil Kerajaan Allah harus diberitakan kapada semua orang, terutama kepada orang-orang yang belum mengenal Injil, seperti penugasan Yesus kepada ketujuh puluh murid (Luk 10:1-12).

Injil adalah berita sukacita yang harus diberitakan kepada segala bangsa melalui para Hamba-Nya, sehingga setiap orang percaya dan mengenal Yesus sebagai Juruselamat dunia. Dalam pelayanan misi Tuhan memakai hamba Tuhan, tentunya dengan penyertaan-Nya melalui kuasa Roh Kudus.

${ }^{171}$ Makmur Halim, Model-Model Penginjilan Yesus..., 34 
Missio Ecclesiae, 5(2), Oktober 2016, 102-133

Melihat betapa pentingnya pelayanan misi, maka dalam bagian akhir ini, penulis memberikan beberapa rekomendasi yang penting untuk disampaikan.

\title{
Bagi Orang Kristen
}

Orang Kristen perlu memahami tentang tugas pelayanan misi dan perlu mengetahui bahwa tugas memberitakan Injil bukan hanya tugas para hamba Tuhan, tetapi merupakan tugas semua orang yang mengaku percaya kepada Yesus Kristus. Orang Kristen harus menyadari bahwa keselamatan bukan hanya untuk dirinya sendiri, tetapi juga untuk orang lain. Orang Kristen harus terlibat dalam pelayanan misi baik melalui pemberitaan Injil secara langsung, maupun melalui kesaksian atau pola hidup tiap-tiap hari dalam profesi yang dijalankan.

\section{Bagi Hamba Tuhan}

Hamba Tuhan harus lebih memahami tentang pelayanan misi secara proporsional, memiliki hati misi dan menyadari sepenuhnya akan panggilan dan tanggung jawabnya sebagai pelaksana misi Allah. Hamba Tuhan perlu memperlengkapi umat Tuhan, supaya memiliki pengetahuan tentang misi, sehingga umat Tuhan dapat terlibat aktif dalam pelayanan misi.

\section{Bagi Lembaga Misi}

Bagi lembaga-lembaga misi, supaya pelayanan misi lintas budaya terus dikembangkan dengan melihat perkembangan zaman saat ini, mempersiapkan para misionaris untuk melayani di negara-negara atau suku-suku yang belum mendengar Injil dengan dukungan baik doa maupun dana.

\section{DAFTAR PUSTAKA}

\author{
1995 Alkitab. Jakarta: Lembaga Alkitab Indonesia \\ Abineno, J.L. Ch \\ n.d Yesus Juruselamat Dunia. Jakarta: BPK Gunung Mulia \\ Balz, Horst dan Schneider, Gerhard \\ 1990 Exegetical Dictionary of The New Testament. Grand Rapids, \\ Michigan: William B. Erdmans Publishing Company
}




\section{Missio Ecclesiae, 5(2), Oktober 2016, 102-133}

Barbara dan Friberg, Timothy

1975 Analytical Greek New Testament. Grand Rapids, Michigan:

Baker Book House

Bock, Darell

1996 Baker Exegetical Commentary on The New Testament Luke Vol

2. Grand Rapids, Michigan: A Division of Baker Book House

Boeker, Trougott

1985 Misi: Kasih yang Mencari. Batu-Malang: Departemen Literatur YPPII

Boland, B. J.

2001 Tafsiran Alkitab Injil Lukas. Jakarta: BPK Gunung Mulia

Bosch, David J.

2005 Transformasi Misi Kristen. Jakarta: BPK Gunung Mulia

Brown, Keith

n.d Pelayanan Misi Dalam Gereja-Gereja Lokal di Asia. BatuMalang: Departemen Misi YPPII

Coleman, Robert

1964 Rencana Agung Penginjilan. Bandung: Kalam Hidup

Drewes, B. F

$2001 \quad$ Satu Injil Tiga Pekabar. Jakarta: BPK Gunung Mulia

Eims, Leroy

1988 Penuai yang Diperlengkapi. Malang: Gandum Mas

Frances, Eddy

2006 Murid Kristus Jilid Dua. Jakarta: Yayasan Sinar Nusantara

Gaebelein, Frank

1984 The Expositors Bible Commentary Vol 8.Grand Rapids, Michigan:

Regency Reference Library 


\section{Missio Ecclesiae, 5(2), Oktober 2016, 102-133}

Graham, Billy

1991 Beritakanlah Injil. Yogyakarta: Yayasan ANDI

Halim, Makmur

1998 Misi Diskusi dan Doa. Malang: Gandum Mas

2000 Gereja di Tengah-Tengah Perubahan Dunia. Malang: Gandum Mas

2002 Model-Model Penginjilan Yesus. Malang: Gandum Mas

Hendriksen, Wiliam

1978 New Testament Commentary, Luke. Endinburgh: The Banner of Truth Trust

Jansen, Irving L.

n.d Lukas Buku Penuntun Belajar. Bandung: Kalam Hidup

Kuiper, Arie De

1967 Misiologia. Jakarta: BPK Gunung Mulia

Lumintang, Stevri I

2006 Theologia dan Misiologia Reformed. Batu-Malang: Departemen Literatur YPPII

2007 Metodologi Penelitian dan Laporan Penelitian Ilmiah. Surabaya: Fakultas Lintas Budaya

Manton, M. E.

2004 Kamus Istilah Teologi Inggris Indonesia.Malang: Gandum Mas

Marshall, Howard

1989 New International Greek Testament Commentary on Luke. Grand Rapids: Wm. B. Eerdmans Publishing Co 


\section{Missio Ecclesiae, 5(2), Oktober 2016, 102-133}

Newman, Barclay

2000 Kamus Yunani Indonesia. Jakarta: BPK Gunung Mulia

Nolland, John

n.d Word Bible Commentary. Dalas Texas: Word Book Publisher

Octavianus, Petrus

1998 Peran dan Pemikiran. Batu-Malang: Departemen Literatur YPPII

1974 Missio Dei, Pengutusan Allah. Batu-Malang: Departemen Literatur YPPII

Pasaribu, Marulak

2004 Eksposisi Injil Sinoptik. Malang: Gandum Mas

Poerwadarminta, W. J. S.

1976 Kamus Umum Bahasa Indonesia. Jakarta: Balai Pustaka

1990 Kamus Besar Bahasa Indonesia. Jakarta: Balai Pustaka

Ridderbos, H. dan Baarlink

1975 Pemberitaan Yesus Menurut Injil-Injil Sinoptis. Jakarta: BPK Gunung Mulia

Rienecker, Fritz

1977 A Linguistic Key to The Greek New Testament. Grand Rapids, Michigan: Reference Library, Regency

Salim, Peter

1989 Kamus Bahasa Indonesia Kontemporer. Jakarta: Modern English Press

Stein, Robert H. 
Missio Ecclesiae, 5(2), Oktober 2016, 102-133

1990 The New American Commentary Luke Vol 24. NashvilleTennessee: Broadman Press

Sutanto, Hasan

1985 Hermeneutik: Prinsip dan Metode Penafsiran Alkitab. Malang: Seminari Alkitab Asia Tenggara

2004 Perjanjian Baru Interlinear Konkordansi Jilid II. Jakarta: Lembaga Alkitab Indonesia

Surjantoro, Bagus

2005 Hati Misi. Yogyakarta: ANDI

Tenney, Merrill

1991 Survei Perjanjian Baru. Malang: Gandum Mas

Thayer, Joseph $\mathrm{H}$

2000 Thayer's Greek English Lexicon of The New Testament. Peabody: Hendrickson Publishers

Tomatala, Yakob

1997 Penginjilan Masa Kini Jidid 2. Malang: Gandum Mas

2001 Teologi Misi. Jakarta: YT Leadership Foundation

Tong, Stephen

1976 Menjadi Pelayan Kristus. Surabaya: YAKIN

Tulluan, Ola

1997 Introduksi Perjanjian Baru. Batu: Departemen Literatur YPPII

1990 Kamus Besar Bahasa Indonesia. Jakarta: Balai Pustaka 
Missio Ecclesiae, 5(2), Oktober 2016, 102-133

1992 New Bible Commentary 21 Century Edition. England: Inter-Varsity Press

2005 Kamus Besar Bahasa Indonesia. Jakarta: Balai Pustaka

2006 Kamus Besar Bahasa Indonesia Edisi Ketiga. Jakarta: Balai Pustaka

2002 Ensiklopedi Alkitab Masa Kini Jilid I. Jakarta: Yayasan Komunikasi Bina Kasih/OMF

2001 The Wycliffe Bible Commentary. Malang: Gandum Mas 